\title{
ПРАВО
}

УДК 342.25

Боярський Володимир Олександрович аспірант Інституту законодавства

Верховної Ради України. ORCID: https://orcid.org/0000-0001-8029-3963

boyarskii.volodymyr@gmail.com

\section{ДОДАТКОВІ ПРОТОКОЛИ ДО ЄВРОПЕЙСЬКОЇ РАМКОВОЇ КОНВЕНЦІЇ ПРО ТРАНСКОРДОННЕ СПІВРОБІТНИЦТВО МІЖ ТЕРИТОРІАЛЬНИМИ ОБЩИНАМИ АБО ВЛАСТЯМИ 1980 РОКУ}

Анотація. В статті зроблена спроба системного аналізу додаткових протоколів Європейської (рамкової) конвенції про транскордонне співробітництво між територіальними общинами або властями 1980 року в контексті їі розвитку. Розкриті особливості їх прийняття і реалізації положень в Україні.

Ключові слова: Європейська (рамкова) конвенція, додаткові протоколи, регіон, адміністративно-територіальні одиниці, співробітництво, міжтериторіальне співробітництво.

Аннотация. В статье предпринята попытка системного анализа дополнительных протоколов Европейской (рамочной) конвенции о приграничном сотрудничестве территориальных сообществ и властей 1980 года в контексте ее развития. Раскрыты особенности их принятия и реализации положений в Украине. 


\section{ПРАВО}

Ключевые слова: Европейская (рамочная) конвенция, дополнительные протоколы, регион, административно-территориальные единицы, сотрудничество, межтерриториальное сотрудничество.

Annotation. The article attempts to systematically analyze the additional protocols of the European (framework) convention on cross-border cooperation between territorial communities and authorities of 1980 in the context of its development. The features of their adoption and implementation of provisions in Ukraine are revealed.

Key words: European (framework) convention, additional protocols, region, administrative-territorial units, cooperation, inter-territorial cooperation.

Постановка проблеми. У сучасному світі в умовах прискорення процесів регіоналізації та інтеграції особливої актуальності набуває таке порівняно нове явище, як транскордонне співробітництво, яке сприяє інтенсифікації політичних, економічних і соціокультурних зв'язків між регіонами держав. Оскільки потреба вивчення транскордонних відносин виникла недавно, вона, будучи вписаною в процес регіоналізації, найчастіше

страждає неповнотою опису і недоліком вивченості.

Зовнішні зв'язки регіонів значно розширюють можливості регіонів, дозволяють їм ефективніше вирішувати поставлені перед ними економічні та соціальні проблеми. Транскордонні контакти регіонів служать додатковими каналами співпраці з сусідніми країнами, за допомогою яких можна вирішити завдання, що не знайшли рішення на міждержавному рівні. Своєю чергою, регіони отримують можливість ефективно розвивати економічні, культурні та гуманітарні зв'язки, вирішувати багато проблем, що безпосередньо зачіпають інтереси людей по обидва боки державного кордону.

Соціальний калейдоскоп $\quad$ 1/2020 


\section{ПРАВО}

Аналіз останніх досліджень $\boldsymbol{i}$ публікацій. Питання міжнародних стандартів місцевого самоврядування на сьогодні $\epsilon$ малодослідженою темою у вітчизняній юридичній науці конституційного права. Перші та успішні спроби в цьому відношенні були зроблені в наукових працях М.О. Баймуратова, О.В. Батанова, П.Д. Біленчука, І. П. Бутка, М. В. Гірняк, В. В. Кравченко, М. В. Підмогильного та ін. Однак ці вчені вивчали це питання або в контексті інших питань формування та розвитку місцевого самоврядування в Україні, або зосереджувались на певних міжнародноправових договорах, що регулюють розвиток місцевого самоврядування в умовах демократії. Отже, систематичне дослідження цих стандартів не проводилось.

Тому, метою статті виступає дослідження додаткових протоколів до Європейської (Рамкової) конвенції про транскордонне співробітництво між територіальними общинами або властями 1980 року, яка стала першим міжнародно-правовим документом у галузі регулювання місцевого самоврядування та співпраці його органів та суб'єктів 3 подібними адміністративно-територіальними одиницями та утвореннями іноземних держав.

Виклад основного матеріалу. До базових міжнародно-правових документів, які регламентують транскордонне співробітництво держав, відносяться Європейська рамкова конвенція про транскордонне співробітництво між територіальними общинами або властями від 21 травня 1980 року [1], Додатковий протокол від 9 листопада 1995 року [2], Протокол № 2 від 5 травня 1998 року [3], Протокол № 3 від 16 листопада 2009 року [4], і Європейська Хартія місцевого самоврядування від 15 жовтня 1985 року [5].

Серед цих документів найбільшу важливість для створення i діяльності форм транскордонного співробітництва являє Європейська рамкова конвенція про транскордонне співробітництво між

Соціальний калейдоскоп $\quad 1 / 2020$ 


\section{ПРАВО}

територіальними общинами або властями (або Мадридська конвенція) та іiі Протоколи, хоча сфера їх дії обмежена рамками Ради Свропи, точніше, територією 47 держав європейського континенту, що є членами цієї організації.

Так, Свропейська Конвенція досить докладно регламентує зміст зобов'язань держав-членів Р€ з організації прикордонного співробітництва. По-перше, вона вводить відповідний понятійний ряд і профільний тезаурус (транскордонне співробітництво, територіально-адміністративні одиниці або влади тощо). По-друге, Конвенція передбачає дві категорії угод, які будуть служити для успішної реалізації прикордонного співробітництва міждержавні угоди про транскордонне співробітництво на місцевому та регіональному рівнях (по типу «міжнародне публічне право») і угоди, контракти і статути, які забезпечать основу прикордонного співробітництва між територіальними владами та громадами (по типу «міжнародне приватне право»).

Крім того, цей документ спонукає держави-члени Ради Європи заохочувати ініціативу місцевих і регіональних влад 3 транскордонного співробітництва, пропонуючи різні його моделі. У Конвенції зазначається, що метою Ради Європи є зміцнення єдності країн-членів та сприяння розвитку співпраці між ними, і потенційне значення для досягнення цієї мети $є$ співпраця прикордонних територіальних общин або влади, в таких областях як розвиток регіонів, міст і сільських районів, охорона навколишнього середовища, вдосконалення суспільної інфраструктури і послуг, взаємодопомога в надзвичайних ситуаціях.

Держави-члени Ради Свропи, які підписали цю Конвенцію, домовилися, що кожна Договірна Сторона зобов'язується сприяти прикордонному співробітництву між територіальними общинами або властями і будь-якій ініціативі територіальних общин або властей, що 


\section{ПРАВО}

заснована на рамкових домовленостях між територіальними общинами або властями.

Доповненнями до даної Конвенції служать взяті в подальшому Протоколи. Перший Додатковий протокол до Європейської рамкової конвенції про транскордонне співробітництво між територіальними общинами або властями був прийнятий 9 листопада 1995 у штаб-квартирі Р€ Страсбурзі (Франція). Основним завданням даного протоколу $є$ розширення положень Рамкової конвенції 3 метою зміцнення прикордонного співробітництва між територіальними общинами або властями [2]. Ухвалення Протоколу означало надання більшої незалежності територіальним общинам або властям в питаннях прикордонного співробітництва, про це свідчить стаття 1 і 2: угода про транскордонне співробітництво тягне за собою відповідальність виключно між територіальними общинами або властями (критерій локалізації відповідальності. - Авт.); рішення, що приймаються в рамках угоди про транскордонне співробітництво, здійснюються територіальними общинами або властями в рамках своєї національної правової системи і відповідно до внутрішнього законодавства (критерій пріоритету національного законодавства. - Авт.). У статті 3 Протоколу № 1 зазначається, що відповідно до угоди про транскордонне співробітництво, може створюватися орган транскордонного співробітництва, який буде виконувати завдання, покладені на нього територіальними общинами або властями (критерій створення локального органу управління профільним співробітництвом. - Авт.).

Наступний документ - Протокол № 2 до Європейської рамкової конвенції, був прийнятий 5 травня 1998 року в Страсбурзі. Його основною метою була реалізація завданням щодо визначення міжнародних правових рамок міжнародного співробітництва у контекстуалізації визначення його просторових меж, - так як для ефективного виконання своїх функцій 


\section{ПРАВО}

територіальні громади та власті все більше співпрацюють не тільки 3 сусідніми (суміжними) властями інших держав (власне транскордонне співробітництво), але також із зарубіжною владою, які не є сусідніми (суміжними), але які мають спільні інтереси (міжтериторіальне співробітництво), i роблять це не тільки в рамках прикордонного співробітництва органів i асоціацій територіальних громад i влади, але також і на двосторонньому профільному міжсуб'єктному рівні. В даному протоколі визначено поняття «міжнародне співробітництво», на підставі чого пояснюється, що у Рамковій Конвенції та Додатковому протоколі вираз «прикордонне співробітництво» читається як «міжтериторіальне співробітництво» 3 метою відповідності та застосування Рамкової Конвенції та Додаткового Протоколу. Отже, Протоколом №2 стверджується, що кожна Договірна Сторона визнає і поважає право територіальних общин або властей в межах іiі юрисдикції проводити переговори і складати в межах загальних сфер відповідальності угоди про міжнародне співробітництво відповідно до процедур, закладеними їх статутами, причому не тільки між суміжними (прикордонними) органами місцевого самоврядування, a i між такими, що не $\epsilon$ суміжними (транскордонними, міжтериторіальними).

У 2004 році Рада Європи та ЄС практично одночасно приступили до розробки нових юридичних інструментів в сфері регіональних об'єднань, покликаних створити єдині правові норми їх утворення та діяльності Регламенту СС №1082/2006 про Свропейські об'єднання з територіальної співпраці [6] та Протоколу №3 до Мадридської конвенції про єврорегіональні об'єднаннях зі співробітництва [4].

Однак розбіжності між РС та СС в єврорегіональній сфері стали загострюватися, так як просування в РС концепції створення подібних структур на базі міждержавних угод фактично підвищує правовий статус зацікавлених адміністративно-територіальних утворень і підігріває

Соціальний калейдоскоп $\quad 1 / 2020$ 


\section{ПРАВО}

політичні амбіції місцевих еліт. Тому на початковій стадії пропозицію Ради створити єдиний загальноєвропейський документ і тим самим запобігти «розриву» європейського правового простору в області єврорегіонального будівництва, підтримки з боку СС не знайшло.

Тому, 5 липня 2006 року Свропарламент і Рада ЄС розробили і схвалили Регламент 1082/2006, де передбачається можливість створення структур прикордонного, міждержавного i/або міжрегіонального співробітництва, іменованих «європейськими об'єднаннями територіального співробітництва» (European grouping of territorial cooperation) (далі - СОТС), виключно з метою соціальної і економічної згуртованості в рамках СС і при строгому дотриманні законодавства зацікавлених країн.

Дане положення про СОТС представляє особливий інтерес, тому що служить юридичною основою для організації співпраці держав-членів СС на регіональному та місцевому рівнях.

Наступним кроком, незважаючи на деяке припинення роботи, було схвалення проекту Протоколу № 3 до Європейської Рамкової Конвенції про транскордонне співробітництво між територіальними общинами або властями, який стосується європейських регіональних об'єднань співпраці, яке відбулося за підсумками поглибленого обміну думками 22 квітня 2009 року в Страсбурзі на 43-ому засіданні Свропейського комітету з місцевої і регіональної демократії (ЕКМРД), органу міжурядової співпраці в рамках Ради Свропи, і подальше його підписання 16 листопада 2009 року в м. Утрехт (Нідерланди).

Даний Протокол №3 цікавий тим, що передбачає можливість створення територіальними громадами і владою нової форми і нового більш інтеграційного рівня співробітництва в організаційній формі «угрупування єврорегіонального співробітництва» (Euroregional cooperation grouping) на території держав-членів Ради Свропи та учасників протоколу. Згідно з цим

Соціальний калейдоскоп $\quad$ 1/2020 


\section{ПРАВО}

документом, телеологічною домінантою такого угрупування є «сприяння, підтримка i розвиток прикордонного та міжтериторіального співробітництва між членами співпраці в сферах їх загальної компетенції в інтересах населення та відповідно до компетенцій, встановленими в національному законодавстві зацікавлених держав» [4]. Отже, Рада Свропи розробила інструмент співпраці на місцевому рівні, схожий із запропонованою в Регламенті 1082/2006 організаційною структурою, а саме EOTC.

Підсумовуючи вищевикладене потрібно відзначити, що основоположні документи 3 регулювання транскордонних регіональних об'єднань були розроблені Радою Свропи.

Незважаючи на те, що перше транскордонне об'єднання було створено в 1958 році, перший документ - Регламент 1082/2006, який регулює діяльність подібних структур, був прийнятий СС тільки в 2006 році. Згодом Рада Європи прийняла Протокол №3 до Свропейської рамкової конвенції, в якому отримав свій відбиток такий інструмент регіонального співробітництва, як об'єднання єврорегіонального співробітництва (OСС), що представляє особливий інтерес.

Україна, незважаючи на чітку тенденцію до централізації влади у пострадянський період, тобто, до початку процесів децентралізації публічної влади, не залишилася осторонь від процесів регіонального транскордонного співробітництва, даючи регіонам можливість участі в міжнародних і зовнішньоекономічних зв'язках.

Українська держава завжди прагнула взяти участь у європейських інтеграційних процесах і завдяки Постанові Верховної Ради України від 14 липня 1993 року «Про приєднання України до Європейської рамкової конвенції про транскордонне співробітництво між територіальними общинами або властями» [7], на запрошення Ради міністрів Ради Свропи, 


\section{ПРАВО}

приєдналася до Свропейської рамкової конвенції про транскордонне співробітництво між територіальними общинами або властями.

Законом України від 24 червня 2004 року «Про внесення змін до Постанови Верховної Ради України «Про приєднання України до Свропейської конвенції про основні принципи транскордонного співробітництва між територіальними общинами або органами влади 1980 р.» та про ратифікацію додаткових Протоколів до Європейської рамкової конвенції про транскордонну співпрацю між територіальними общинами або органами влади», - Протокол I та Протокол II до Конвенції були ратифіковані [8]. В даний час триває робота 3 підготовки до ратифікації Протоколу III Україною.

У 2004 році було прийнято Закон України «Про транскордонне співробітництво», який визначав єврорегіон як організаційну форму співпраці адміністративно-територіальних одиниць (регіонів) європейських держав відповідно до двох або багатосторонніх угод про транскордонне співробітництво [9].

В Україні по периметру державних кордонів організовано 8 єврорегіонів, які можуть виконувати роль інституційних утворень. Пріоритетними напрямками єврорегіонів $є$ розвиток інфраструктури, створення інтегрованого транскордонного регіону, розвиток сільських територій, охорона навколишнього середовища, співпраця у галузі навчання тощо [10, с. 90].

Слід мати на увазі, що транскордонне співробітництво - це особлива сфера зовнішньоекономічної, політичної, екологічної, культурної, освітньої та іншої міжнародної діяльності. Воно здійснюється на регіональному рівні, охоплюючи всі форми цієї діяльності, і характеризується потребою та можливостями для більш активного використання; наявність кордону та необхідність його облаштування; загальне використання природних ресурсів i, відповідно, загальне вирішення проблем екологічної безпеки; 


\section{ПРАВО}

більш широке взаємне спілкування населення сусідніх держав, особисті зв'язки людей та збільшення навантаження на інфраструктуру [11, с. 68]. Отже, саме в рамках такої співпраці можна залучити новітні та якісні форми місцевого економічного співробітництва, які включають створення транскордонних фінансово-економічних кластерів [12].

Висновки. Аналіз Європейської (Рамкової) конвенції про основні принципи транскордонного співробітництва між територіальними общинами або органами влади 1980 року та Додаткових протоколів до неї дозволяє зробити наступні висновки:

- згадані міжнародні угоди містять системний блок основних міжнародно-правових норм з питань транскордонного співробітництва;

- ці міжнародні угоди, ратифіковані Україною (крім Додаткового протоколу № 3), дуже важливі для концептуальної розробки не лише стратегії українського прикордонного співробітництва, а й концепції регіональної політики України, що об'єктивно зумовлено активністю України у європейському міжрегіональному співробітництві та загальноєвропейській міждержавній інтеграції;

- реалізація проєвропейських зусиль України безпосередньо пов’язана 3 активною участю іï державних установ та органів місцевого самоврядування, що репрезентують свої територіальні громади, у транскордонному співробітництві.

\section{Список використаних джерел:}

1. European Outline Convention on Transfrontier Cooperation between Territorial Communities or Authorities. - URL: http://conventions.coe.int/Treaty/en/Treaties/Html/106.htm 


\section{ПРАВО}

2. Additional Protocol to the European Outline Convention on Transfrontier Cooperation between Territorial Communities or Authorities. URL: http://conventions.coe.int/Treaty/en/Treaties/Html/159.htm

3. Protocol No. 2 to the European Outline Convention on Transfrontier Cooperation between Territorial Communities or Authorities concerning interterritorial cooperation. - URL: http://conventions.coe.int/Treaty/en/ Treaties/Html/169.htm

4. Protocol No. 3 to the European Outline Convention on Transfrontier Cooperation between Territorial Communities or Authorities concerning Euroregional Cooperation Groupings (ECGs). -URL: http://conventions.coe.int/Treaty/en/Treaties/Html/206.htm

5. European Charter of Local Self-Government. - URL: http://conventions.coe.int/treaty/en/treaties/html/122.htm

6. Regulation (EC) No 1082/2006 of the European Parliament and ofthe Council of 5 July 2006 on a European grouping of territorial cooperation (EGTC) // Official Journal of European Union. - URL: http://ec.europa. eu/regional_policy/sources/docoffic/official/regulation/pdf/2007/gect/ce_1082(2 006) en.pdf

7. Про приєднання України до Європейської рамкової конвенції про транскордонне співробітництво між територіальними общинами або властями: Постанова Верховної Ради України від 14 липня 1993 року // Відомості Верховної Ради України. 1993. № 36. Ст. 370.

8. Про внесення змін до Постанови Верховної Ради України «Про приєднання України до Європейської конвенції про основні принципи транскордонного співробітництва між територіальними общинами або органами влади 1980 року» та про ратифікацію додаткових протоколів до Європейської рамкової конвенції про транскордонне співробітництво між територіальними общинами або властями: Закон України від 24 червня 2004 року // Відомості Верховної Ради України. 2004. № 50. Ст. 534.

Соціальний калейдоскоп $\quad 1 / 2020$ 


\section{ПРАВО}

9. Про транскордонне співробітництво: Закон України від 24 червня 2004 року // Відомості Верховної Ради України. 2004. № 45. Ст. 499.

10. Мікула Н. Сврорегіони: досвід та перспективи. - Львів: ІРД НАН України, 2003. 222 с.

11. Войнаренко М. П. Кластерные модели объединения предприятий в Украине // Экономическое возрождение России. 2007. № 4(14). C. $68-82$.

12. Концептуальные основы формирования трансграничных финансовых кластеров [Електронний документ]. - Режим доступу: http://www.evr.ru/index.php?option=com_content $\&$ view=article\&id=546:2010-07-05-0708-\& catid=300:2010-04-21-14-08-28\&Itemid=114 